\title{
Welfare state context, female labour-market attachment and childbearing in Germany and Denmark
}

\author{
Gunnar Andersson • Michaela Kreyenfeld • \\ Tatjana Mika
}

Published online: 15 October 2014

(C) The Author(s) 2014. This article is published with open access at Springerlink.com

\begin{abstract}
This study investigates the role of female labour-market attachment and earnings in childbearing progressions in two very different European contexts. By applying event-history techniques to German and Danish register data during 1981-2001, we demonstrate how female earnings relate to first, second and third birth propensities. Our study shows that female earnings are positively associated with first birth fertility in Denmark, while this is not the case in West Germany. We interpret our findings based on the fact that Danish social context and policy encourage women to establish themselves in the labour market before becoming mothers, while the German institutional context during the 1980s and 1990s was not geared towards encouraging maternal employment. For higher-order births, the results are less clearcut. For Denmark we find a slightly positive correlation between female earnings and second-birth fertility, while the association is somewhat negative for third-order births. In Germany, women tend to leave the labour market when becoming mothers. Non-employed mothers have elevated second and, in particular, third-birth rates. For the group of mothers who are employed, we find only a weak association between their earnings and higher-order fertility.
\end{abstract}

Keywords Female employment $\cdot$ Fertility $\cdot$ Welfare state context $\cdot$ Register data

\author{
G. Andersson $(\bowtie)$ \\ Demography Unit, Stockholm University, Stockholm, Sweden \\ e-mail: gunnar.andersson@sociology.su.se \\ M. Kreyenfeld \\ Max Planck Institute for Demographic Research, Rostock, Germany \\ M. Kreyenfeld \\ Hertie School of Governance, Berlin, Germany \\ T. Mika \\ Research Data Centre, German Federal Pension Insurance, Berlin, Germany
}




\section{Introduction}

In the not-so-distant past, female employment was regarded in the literature as a barrier to family formation. Underlying this view were the assumptions that childrearing and employment are incompatible activities, and that a gendered division of household duties can be expected to prevail. Increases in female education, income and employment would thus result in lower fertility. Empirical studies for the 1960s and 1970s, when fertility in many countries declined in tandem with increasing female labour force participation, lent support to this hypothesis. The evidence was overwhelming, and for many scholars the negative correlation between female employment and fertility became a matter of fact (Becker 1993; Spitze 1988).

However, the idea that female employment is always a threat to reproduction has been disputed vigorously in more recent sociological and demographic literature. Proponents of comparative welfare state research have pointed out that policies in modern societies that help mothers to combine work and family life are also conducive to higher fertility (Bernhardt 1993; Esping-Andersen 1999, 2009; Gauthier 2007; Matysiak and Vignoli 2013; McDonald 2000; Neyer and Andersson 2008). The male-breadwinner family model, which was dominant for several decades, has increasingly become viewed as a precarious arrangement. Growing labour market uncertainties, increasing family dissolution rates and changing aspirations of women and men have consecutively eroded the foundation of this family model. Nowadays, the dual-earner family is regarded as more adapted to the various challenges posed by changing family structures and growing labour market uncertainties (Crompton and Lyonette 2006; Ellingsæter 2009; Esping-Andersen 1999, 2009; Hook 2010; Mandel and Semyonov 2006; Thévenon 2006).

From these considerations it follows that social policies and institutions that enable or hinder mothers' participation in the labour market also influence fertility behaviour (Bernhardt 1993; Castles 2003; Esping-Andersen 1999, 2009; Luci and Thévenon 2011; McDonald 2000; Neyer and Andersson 2008; Rindfuss and Brewster 1996; Sørensen 1991). Furthermore, welfare-state setups, social institutions and social policies are likely to influence the correlation between women's labour-force participation and their fertility (e.g., Neyer 2013). In societies that support the male-breadwinner model, women's earning power is likely to be negatively related to fertility; in dual-earner societies, the association may be the opposite. When both women and men are expected to work, a person's gainful employment may become a prerequisite for having children, regardless of the person's sex.

Despite the significance of these assumptions, there is only sparse micro-level evidence that shows that high female earnings and employment may translate into higher fertility. In this study, we contribute to filling this gap by investigating how female labour-market attachment and earnings relate to fertility in the two very different welfare-state contexts of Denmark and Germany. The two neighbouring countries seem ideal test cases for studying how institutional context shapes the association between female employment and fertility. While Denmark's family policies have gradually shifted towards supporting maternal employment since the 
1970s, Germany's family policies have continued to favour the housewife model. Given the contrasting welfare state setups, women in these two countries must have adopted different strategies to synchronize fertility with their employment ambitions. In order to understand these strategies, we address the following questions: at what stage in their employment careers do women opt for parenthood? Do they choose to become mothers when they have acquired stable employment and enjoy earnings that are large enough to support a family? Or are their own earnings and employment conditions unrelated to fertility timing and parity progression, or even detrimental to family building? How do patterns vary by birth order? How have they evolved over calendar time? To what extent can we attribute existing patterns to the different institutional contexts of West Germany and Denmark?

In order to answer these questions, we make use of large-scale register data for the period 1981-2001. Since the demographic situations in the two parts of Germany were and still are very different from each other, we focus our attention on West Germany and do not study East Germany. ${ }^{1}$ While a considerable amount of register-based social science research has been conducted for the Nordic countries, these opportunities have so far been very limited for Germany. This contribution is to our knowledge the first study to draw upon register data to compare the fertility behaviour in Germany with that in a Nordic country. Given the shrinking response rates in social science surveys and the problems attributed to the collection of reliable longitudinal employment and earning histories, we trust that register-based research of this kind is an important way to generate more reliable empirical results. This being said, there are also disadvantages associated with using register data, particularly when it comes to the range of variables that researchers can use; our study is no exception to this. Apart from female earnings, we can rely on only a few basic demographic variables. Thus our investigation may not turn into a fully comprehensive analysis of the association between female earnings and fertility, but it still offers a descriptive and highly accurate study on the association between women's labour-market attachment and fertility timing. The article is structured as follows. In the next section, we generate our main hypotheses and provide a brief overview of the institutional framework and fertility context of Denmark and Germany. Thereafter, we present our data and methods and the results of our eventhistory analysis of the transitions to first, second and third childbirth.

\section{Theoretical considerations}

Theories on the relationship between female earnings, employment and fertility

The relationship between economic and employment conditions and fertility is of prime interest for demography, family sociology and family economics. Malthus claimed in his famous Essay on the Principles of Population from 1798 that

\footnotetext{
${ }^{1}$ In this study, the term 'West Germany' refers to the region that until 1990 belonged to the Federal Republic of Germany. For the time after German reunification, 'Western Germany' would be a more appropriate term. For the sake of simplicity, however, we use the term 'West Germany' for the periods both before and after 1990 .
} 
economic hardship might induce people to delay marriage and childbearing. Since then, the idea that "people should wait until they can "afford" to make the transition to parenthood' (Rindfuss et al. 1988, p. 21) has remained prominent in economic and sociological demographic thinking. Likewise, it has been a common understanding that it is the man's earnings and his labour market performance that matters in fertility decisions. Female earnings have often been approached by the 'role-incompatibility argument', based on the dual assumptions that work and family life are not compatible and that women have the lion's share of childrearing tasks. The growth in earning power and labour-market activity of women was thus regarded as a major cause of fertility decline. The role-incompatibility argument was used as the standard framework in many empirical studies dealing with fertility behaviour during the 20th century (Borg 1989; Brewster and Rindfuss 2000; Budig 2003; Matysiak and Vignoli 2008).

However, what was a valid argument in the past no longer reflects the reality of employment and family behaviour of many parents in contemporary Europe. In several countries, welfare state institutions have accommodated the needs of working parents by expanding public daycare and introducing more generous parental leave regulations. At the same time, maternal employment rates have increased, which has resulted in an upsurge of the dual-earner family arrangement and a decline of the male-breadwinner family (Blossfeld and Drobnic 2001; Crompton and Lyonette 2006). These changes have not only relaxed the validity of the role-incompatibility argument; they have also made the welfare state institutions the focal point of much research on employment and fertility decisions in contemporary societies.

Proponents of comparative welfare state research highlight the role of social policies in shaping patterns in female employment (Daly 2005; Gornick et al. 1998). Furthermore, Esping-Andersen $(1999,2009)$ has been very influential in pointing out that the welfare state context not only influences patterns in female employment and gender roles, but also is able to explain much of the fertility variation across Europe. Based on cross-sectional correlations of female employment and fertility rates in OECD countries, Esping-Andersen (1999) showed how the association between female employment and fertility changed from being negative in the 1980s to positive in the 1990s. Esping-Andersen's empirical approach has been extended, discussed and criticized in further studies (Ahn and Mira 2002; Castles 2003; Kögel 2003); however, his argument has remained essential for the understanding of fertility dynamics in contemporary Europe. Accordingly, countries that are unable to modernize their family policies by improving the compatibility of employment and family life will experience reduced fertility; countries that resolve the incompatibility of work and family life will experience higher fertility. When the role of women shifts from being mainly caregivers to also being income providers, a woman's gainful employment may become a prerequisite for forming a family, and high female earnings may enable couples to have a larger family. Providing empirical support for individual-level associations of this kind would produce further and more conclusive evidence of the 'seismic shifts in the historic relationships between fertility rates and other variables' (Castles 2003, p. 213). 
Welfare state policies and gender equality in Germany and Denmark

If one seeks to investigate how welfare state policies shape the association between female earnings and childbearing, the two neighbouring countries of Germany and Denmark seem ideal cases for comparison. While Denmark has consecutively modernized its family policies since the 1970s, Germany's family policies have been rather slow in catching up with the demands of working mothers; in particular, little effort has been made to support maternal full-time employment. Child care for children under age three has largely been unavailable, while for older children only part-time care has been available (Hank and Kreyenfeld 2003). Parental leave regulations have been criticized for providing too long and too lowly compensated periods of leave: after 1992, parents became entitled to job-protected leave of a maximum duration of 3 years per child. Additionally, the tax system, public pension regulations and the health care system all provide benefits to married couples who pursue a traditional division of labour. The German system of joint taxation of spouses is well renounced for encouraging gendered divisions of labour-market and care work (Sainsbury 1999). Some of this began to change in 2007, when the government launched a major family policy reform which brought Germany's social policies more in line with those of the Nordic countries (Henninger et al. 2008). Yet Germany has for many decades been a clear prototype of a conservative welfare regime that until very recently gave strong disincentives for maternal employment.

In contrast, Denmark, like other Nordic countries, has since the 1970s radically reformed its family policies. Even though parental leave regulations have been less comprehensive than in Sweden, Denmark's family policies are usually praised for their family-friendliness (Abrahamson and Wehner 2008; Ellingsæter and Leira 2006; OECD 2002). Like other Nordic countries, Denmark has gradually expanded public day care and improved parental leave conditions. Denmark stands out as a country with exceptionally high child care coverage also for children under age 3 . In 2006, more than $70 \%$ of children aged 0-2 attended day care, while this held for less than $10 \%$ of children at similar ages in West Germany (European Commission 2009: 30; Kreyenfeld and Krapf 2010: 114). Family policies and social institutions in Denmark have encouraged women to return to the labour market swiftly after childbirth, and a large fraction of them do so on a full-time basis (Grunow 2006; Pylkkänen and Smith 2003; Rostgaard et al. 1999). Apart from family policies, also the Danish labour market with its large public sector and the renowned system of 'flexicurity' in employment provides more advantageous conditions to reconcile work and motherhood. The wage penalty of motherhood is indeed relatively low in Denmark. In a study comparing the gender wage gap across Europe, Gash (2009: 583) finds that Denmark is the country with the lowest motherhood penalty. At the other end of the spectrum are West Germany and the UK with the highest wage penalties of motherhood.

In Denmark and West Germany, women's employment rates have increased over time (Fig. 1). The increase in Denmark mainly took place during the 1960s and 1970s; in Germany the corresponding development started more than twenty years later. During the 1980s and 1990s, which is the focus of our study, female employment rates were about 10-20 percentage points higher in Denmark than in 


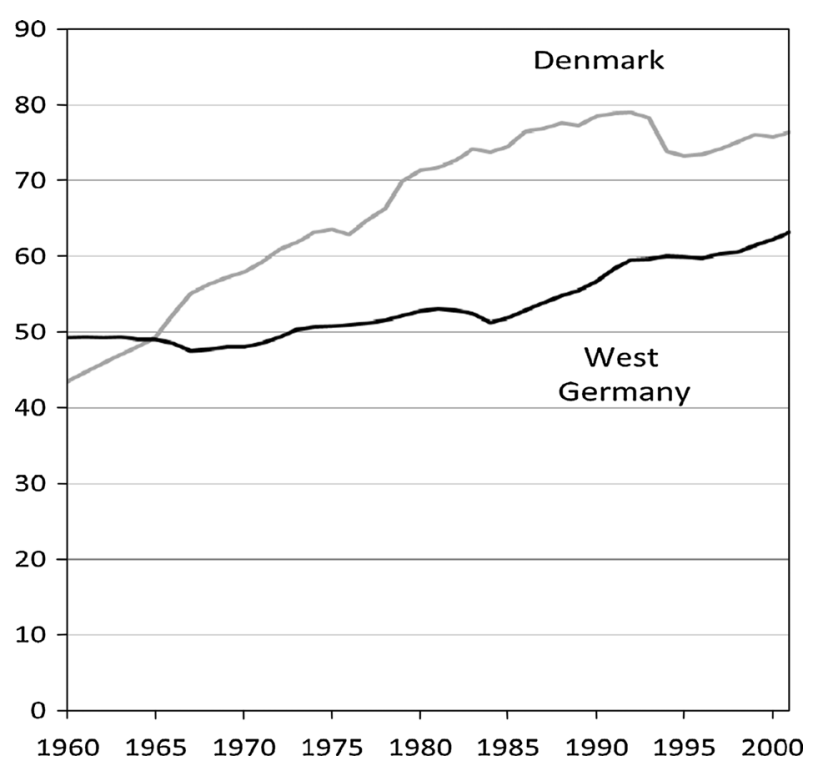

Fig. 1 Female employment rates, ages 15-64, Denmark and Germany, 1960-2001. Source: Kreyenfeld and Geisler (2006), Neyer et al. (2006). West Germany includes West Berlin

Germany. In 2011, the employment rates of Denmark and Germany had converged at $73 \%$ (OECD 2012). However, the recent convergence in official employment rates conceals major differences in behaviour between the two countries. Whereas the increase in Germany was largely due to an influx of part-time employees (Konietzka and Kreyenfeld 2010), the much earlier increase in Denmark was attributed to increases in full-time employment. In fact, part-time employment of women in Denmark has stalled since the early 1990s (Warren 2001). In 2011, 65 \% of working mothers were employed part-time in Germany, while this applied to $31 \%$ of working mothers in Denmark (Eurostat 2013).

Fertility dynamics in Germany and Denmark

If one turns to aggregate fertility developments of (West) Germany and Denmark, the idea that Denmark's family-friendly welfare state may support childbearing seems to be buttressed. West Germany and Denmark both experienced steep fertility declines during the 1960s and 1970s (Fig. 2). In the early 1980s, the period Total Fertility Rate (TFR) of both countries reached 1.4 children per woman, which at that time was the lowest TFR of any sizeable country in the world. However, since 1983 Danish fertility rates have increased more or less continuously. Today Denmark, together with France and the other Nordic countries, has one of the highest period fertility rates in Europe. In contrast, West Germany's TFR developments have taken an entirely different turn. For close to four full decades, its TFR has remained amazingly stable at a level of only 1.3-1.4 children per woman. Even though period fertility measures may be distorted by tempo changes in childbearing behaviour, the 


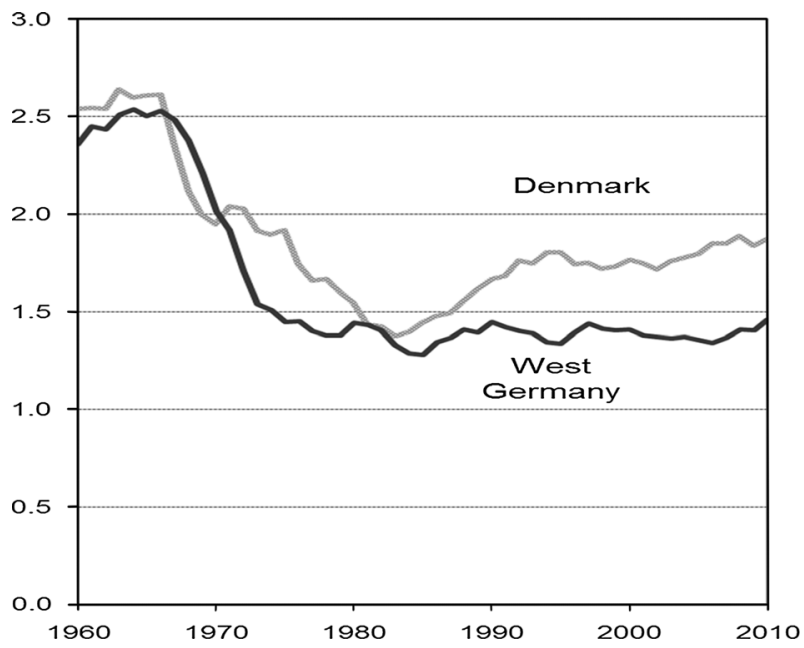

Fig. 2 Total fertility, Denmark and West Germany, 1960-2010. Source: Human Fertility Database (2013), Statistics Denmark (2013a). West Berlin is excluded from the time series after 2000

differences in period TFRs between Denmark and West Germany provide a good illustration of how divergent fertility levels in the two neighbouring countries have become. In fact, tempo effects have distorted the TFR in both countries equally as the ages at first birth have increased at a notably similar pace. In the mid-1970s, the mean age at first birth was 24 years in both countries; in 2010, it had increased to 29.2 years in West Germany and 29.1 years in Denmark (Pötzsch 2012: 91; Statistics Denmark 2013a, b).

Cohort fertility data confirm the observation that fertility levels in the two countries are at opposite ends of the European scale. The most recent cohorts in Denmark to have completed their reproductive careers had on average 1.8 children per woman, which is less than in the other Nordic countries (Andersson et al. 2009). Still, what matters for our comparison is that there is no indication of any continuing declines in completed fertility for these Danish cohorts. On the contrary, Andersson et al. (2009) demonstrate upward trend reversals in ultimate fertility for the Nordic cohorts born during the 1950s with minor increases in recent cohort fertility in all Nordic countries including Denmark. In West Germany, on the other hand, cohort fertility has seen a gradual decline. For the cohorts born in 1940, ultimate fertility still amounted to 2.0 children per woman, while it had declined to only 1.5 children per woman for the cohort born in 1965 (Human Fertility Database 2013). Part of the low West German fertility is attributable to the high levels of childlessness in more recent cohorts: more than $20 \%$ of the West German cohort of women born in 1960-1964 have remained childless (Konietzka and Kreyenfeld 2013). Against the background of high prevalence of childlessness, researchers have diagnosed a polarized fertility pattern for West Germany. According to this concept, behaviour of women has bifurcated into the group of career oriented women who remain childless and the women with low employment ambitions who opt for family life (Huinink 2002; Konietzka and Kreyenfeld 2010). In Denmark, as in the other 
Nordic countries, there is no evidence of such bifurcation. For women born in Denmark in 1955-1959, $14 \%$ of those with low or medium-level education remained childless. Among women with tertiary education the corresponding fraction was $15 \%$ (Andersson et al. 2009). Educational differences in completed fertility were equally small.

Previous findings on female earnings and childbearing in contexts in Europe

The overall developments described above indicate that welfare state context seems to have a role to play in explaining the divergent fertility patterns of West Germany and Denmark. The overall picture also supports the idea that the integration of women into the labour market, as is characteristic for Denmark, is conducive to higher fertility. The two country cases further suggest that the welfare state may shape the association between women's employment and earning power and their childbearing behaviour. While these macro-level patterns provide suggestive evidence of associations, the micro-level evidence for the association between women's economic performance and fertility in different contexts in Europe is mixed.

In a meta-analysis, Matysiak and Vignoli (2008) summarize findings from 30 micro-level studies that addressed the association of female employment and birth behaviour. While the 'classical' negative correlation largely is found for western and southern European countries, it is not reported for northern and post-socialist countries, where women's work is rather found to be conducive to childbearing. While many of the earlier studies often failed to distinguish between employment, unemployment and other types of non-employment, more recent studies have paid greater attention to the role of female unemployment and different aspects of labour-market uncertainties in fertility decisions (Kreyenfeld et al. 2012). For example, Schmitt (2012a) compares the association between female unemployment and first birth risks in three European countries and finds that own unemployment is positively related to first birth risks in the UK and Germany, but not in France. Similar findings are reported in a UK-France comparison by Rendall et al. (2009). This is consistent with the observation that French society supports maternal employment and that the dual-earner family here largely is taken for granted, while this is neither the case in Germany nor in the UK. The positive correlation between female unemployment and first birth risks for Germany is confirmed by studies of Kreyenfeld (2010), Özcan et al. (2010), Schmitt (2012b) and Schröder (2010). Recent studies have, however, highlighted the importance of groupspecific differences in effects. While highly educated women seem to postpone first childbearing during periods of unemployment, the opposite often holds for the less educated (Kreyenfeld and Andersson 2014).

Studies for Nordic countries report strongly negative correlations between female non-employment and first-birth behaviour but only weak associations of female unemployment with first-birth fertility (Andersson 2000; Andersson and Scott 2005; Jalovaara and Miettinen 2013; Kravdal 2002; Lundström and Andersson 2012; Vikat 2004). On the whole, micro-level research largely supports the hypothesis that the institutional context may shape the association between female employment and first-birth behaviour. Regarding higher-order births, patterns appear somewhat less clear. Studies for Germany confirm a negative association between female 
employment and second and higher-order fertility (Alich 2006; Kreyenfeld and Zabel 2005). For the Nordic countries, related research generally reports weak associations between female employment and the continued childbearing of mothers, in particular for second births (Andersson 2000; Andersson and Scott 2007; Kravdal 1992; Oláh 2003; Vikat 2004).

When turning to the association between female earnings and fertility, we must conclude that available studies are rare and the evidence sometimes inconclusive. One reason for the scarcity of empirical evidence is that the necessary analysis requires fertility data as well as prospective earnings information at the individual level; these are rarely available together. A relatively large body of research exists mainly for the Nordic countries. Andersson (2000) used register data on Swedish women's annual earnings during the 1980s and 1990s and found a strong positive association between earnings and first-birth rates, but only weak associations with second- and third-birth behaviour. These findings were supported by a recent study by Silva (2014) based on register data for Sweden that covers the period 1968-2009. Vikat (2004) reports very similar results for Finland based on Finnish register data. Using survey data for Norway and Finland, Rønsen (2004) found, however, a negative role of female wages in fertility. For Italy, Rondinelli et al. (2010) used survey data and reported some negative effects of female earnings on first-birth fertility in the Italian context, but hardly any effects on higher-order childbearing; this finding is supported by a related study on first births in Italy by Vignoli et al. (2012). However, Santarelli (2011) finds that Italian women's level of earnings is not associated with their first-birth rates. The only study of Denmark that we are aware of is by Berninger (2013) who uses data from the European Community Household Panel (ECHP): she finds a positive association of female earnings and first-birth rates in Denmark. However, because of the small number of events in the data (154 first births) and a rather short observation window, the author herself questions the robustness of the finding (Berninger 2013, p. 106).

On the whole, previous research does not always provide consistent evidence on how female earnings relate to fertility in a given context. This largely stems from different operationalizations of earnings, depending on the researcher's discipline. While sociological and demographic studies regularly focus on the role of current earnings in childbearing behaviour, economists prefer to use predicted wages as input in their fertility models (e.g., Rondinelli et al. 2010; Rønsen 2004). Differences in operationalization stem from differences in theoretical approaches. Economists are mainly concerned with the causal effects of forgone earnings on fertility; other social scientists are more concerned with how the actual employment and earning situation of women interrelates with different life course choices. Some inconsistencies in previous research are also due to the fact that many studies rely on rather small samples of survey respondents with only a few observations covered.

\section{Hypotheses}

With our study, we seek to provide new empirical evidence on the relationship between women's earnings and their fertility by presenting a cross-country comparison that draws on large-scale register data of Denmark and West Germany. 
Our aim is to investigate how female employment and earnings are associated with fertility in these two European contexts. Further, we seek to detect whether there are differences in these associations by women's birth order and age and how associations may have changed over calendar time. Our earnings data cover registered earnings from gainful employment. We have no information on working hours and are thus unable to tell whether any earnings stem from full-time or parttime work. We have no access to comparable data from both countries on transfer payments or data on partnership status and, consequently, on any partner's earnings, which may be a decisive factor that determines fertility choices in the malebreadwinner regime of Germany in particular. With these limitations we set out to provide empirical evidence of how the earnings situation of women relates to their childbearing, and how patterns vary by welfare state context.

For West Germany, one would presume that female earnings and first-birth rates are negatively related or unrelated to each other. Women in West Germany do not expect to be prime family wage earners and for them there is little reason to postpone parenthood if they have not established themselves in the labour market. We would probably expect a negative association of female employment, earnings and first-birth rates based on the abovementioned polarized fertility pattern in which career-oriented and high-earning women often remain childless. In our event-history analysis this should show up in reduced first-birth rates among high-income women. In contrast, Danish social policies have increasingly enabled women to combine full-time employment and family life over the life course. At the same time a growing conviction has emerged 'that a dual full waged household was increasingly necessary for families to get by in the Danish economy' (Warren 2001, p. 560). This suggests that it is of vital importance for Danish women to establish themselves in the labour market before considering having children; we thus expect a positive association between female earnings and first-birth rates in this country. This pattern would also be supported by the parental leave system that sets incentives to get established in the labour market before having children. As in the rest of Scandinavia, Denmark has a parental leave system where leave benefits are related to prior earnings. However, the development of this system was slower in Denmark than in other Nordic countries; during our study period it was not un-common for Danish women to prolong their nominal parental-leave periods by relying on supplementary benefits from various other labour-market and unemployment programs (Cedstrand 2011). Still, what matters is that both parental leave and unemployment benefits are designed to compensate for the forgone earnings of the non-working adult. In contrast, in Germany parental leave benefits used to be paid on a flat-rate basis. The low benefit of 300 Euro was never meant to compensate for a forgone income, but as a measure to acknowledge the value of childrearing for society.

Family policies in Denmark have, however, not developed uniformly towards supporting gender equality. Compared to other Nordic countries, the share of men on parental leave is rather low (Ellingsæter and Leira 2006; Haataja 2009; Rostgaard et al. 1999). The paternity quota, which has been extended over time in other Nordic countries, was even abolished in 2002, after being in place for only 4 years (Borchorst 2006). Also other developments in Danish family policy have 
been rather ambivalent. In reaction to the recession at the beginning of the 1990s, Denmark introduced a 'child care leave' which allowed parents of children aged 0-8 years to take additional paid leave of up to 52 weeks (see discussion above). This benefit was initially reserved for employed parents, but subsequently expanded to the unemployed. Noteworthy in this respect is that Denmark stands out with its high share of unemployed among parental leave benefit recipients (Bruning and Plantenga 1999: 203). These aspects obscure the image of Denmark being a country that uniformly strives for gender equality and maternal labour market integration. Nevertheless, Danish social policies, characterized by individual taxation, earningsrelated parental leave and wide availability of child care, are clearly more geared towards the integration of women into the labour market than are German social policies.

The association between female earnings and higher-order childbearing is influenced by the employment patterns that women adopt after they have become mothers. In the case of Germany, we suspect patterns based on bifurcation in childbearing behaviour: career-oriented and high-income women more often remain childless and those with a low labour market attachment more often have children. High-income women who are at risk of having a second or third birth must therefore belong to a relatively select population in preferences for motherhood and family building as well as in respect of their abilities to combine work and family life (Brodmann and Esping-Andersen 2007; Kreyenfeld 2002). Owing to this selectivity, high-income women may have elevated second and third-birth rates, resulting in a positive correlation between female earnings and higher-order fertility. However, the aspect that dominates the situation may more likely be the strong incompatibility of work and family life to which the majority of West German women are subject. These incompatibilities are balanced through the labour market withdrawal and part-time or marginal employment of mothers. A strong labour market attachment of a West German woman may thus be reflected in a reduced propensity to have another child. Taken together, in the case of West Germany we expect a negative association between female earnings and second and third-birth rates to dominate.

Also in Denmark, which is praised for its family-friendly policies, women have the lion's share of household and childrearing tasks, and some women resolve the family-work conflict by reducing their working hours after the first birth (Fine-Davis et al. 2004: 43; Lister 2009: 255). In many cases, this may make it easier to pursue continued family building; however, the large majority of mothers return to work full-time. As a double income in Denmark is deemed a prerequisite for maintaining a sufficient standard of living, one would assume that high female earnings are beneficial for having additional children. High-income women have better means to support a larger family and may thus experience higher second- and third-birth rates. In practice, these considerations may matter more for third birth decisions than for second births. Previous research on other Nordic countries reveals that in societies with a strong two-child norm and high progressions to the second birth, earnings matter relatively little in second-birth behaviour (e.g., Andersson 2000; Vikat 2004). For third births, both types of considerations discussed above may matter and we may expect a bifurcation in childbearing behaviour, where third-birth rates are elevated both for the group of women who have a reduced attachment to 
the labour market and for those who are successful in maintaining their earning power (Berinde 1999).

\section{Method and data}

Method

In methods, we apply event-history modelling. The event-history approach is particularly suited for our purpose as it treats earnings as time-dependent variables in the fertility process. This enables us to account for the fact that a woman's earnings may change over her life course; it also takes the temporal order of earnings and fertility choices seriously as earnings are always measured before any possible childbirth. This is of particular importance if women change their employment behaviour after having children. In this investigation, we therefore study how current earnings relate to fertility. In the German data, we are able to use monthly earnings; in the Danish data we have annual earnings at our disposal.

We estimate separate models for each birth order. ${ }^{2}$ In the first-birth model, the process time is represented by a woman's age and modelled as a piecewise constant function. For second and third births, it is the duration since previous birth. Time is measured in months. Observations are censored at age 45, emigration, death, or the end of 2001, whichever comes first. ${ }^{3}$ The major independent variable of interest in our modelling is the woman's earned income, measured in earnings quintiles, and other information on the woman's labour market status; calendar year is a control variable. For higher-order births, we also control for the woman's age as a timevarying covariate. Below is a more detailed account of how these variables are defined.

Data

For Germany, we use a sample of data from the German Statutory Pension Insurance (Deutsche Rentenversicherung Bund). ${ }^{4}$ Data for Denmark come from the

\footnotetext{
2 An alternative approach would have been to model all birth orders jointly including a parameter for unobserved heterogeneity in childbearing progressions (e.g., Kravdal 2001). While the latter approach is a more refined technique to unravel causal determinants of fertility, it also has drawbacks related to assumptions on unobserved heterogeneity as a time-constant trait and bound to follow a given frailty distribution. In our case, we chose to rely on observed variables and produce descriptive findings that are accessible to a wider academic audience.

${ }^{3}$ In the German data, cases are also censored at last observed data clearance (Kontenklärung): This is the point in time when the German Pension Fund checks the information that is, so far, available in the pension records (Kreyenfeld and Mika 2008). Clearance takes place at various stages in the life course, but usually not before age 30 . The large majority of cases in our sample underwent the last clearance past age 45. Therefore, most cases are either censored at age 45 or the end of 2001.

4 The data have been made available by the Research Data Centre of the German Statutory Pension Insurance (Stegmann 2007; Rehfeld and Mika 2006). The data extract that is used is the combined Versichertenkontenstichprobe 2002, 2005 and 2007. This is a $1 \%$ sample of the original pension records, and it includes women born in 1935-1992. To make the sample comparable to the Danish data, we limited it to calendar years 1981-2001 and ages 20-44. Note that data clearance procedures at the
} 
country's population register system, in which population data have been merged with data from various other administrative registers. The Danish data cover the entire resident population of the country. For both countries, we focus our analysis on women aged 20-44, thus, leaving out teenage/school-age fertility. The calendar period we cover is 1981-2001. In both datasets foreign nationals/foreign-born women have been excluded, ${ }^{5}$ because we do not want to consider the various confounding associations of international migration with childbearing behaviour (Andersson and Scott 2005, 2007). For Germany, we also exclude all eastern German women. ${ }^{6}$ While we have tried to make the datasets as comparable as possible, each of the datasets has certain peculiarities that should be noted.

\section{Characteristics of the German and Danish datasets}

A significant advantage of the German data is that they contain accurate monthly information on the employment and earnings situations of included individuals since age 14. For females, the data also include information on the dates of each childbirth (see Kreyenfeld and Mika 2008). German law makes it difficult to merge administrative data from different sources, and there is no other register dataset for Germany that contains both complete fertility and employment histories. Fertility data are contained in the pension register because childrearing is taken into account in calculating an individual's pension rights. However, there are also disadvantages to this dataset. First, the data include only persons who are covered in the statutory pension insurance of Germany; this applies to more than $90 \%$ of the German population and about $95 \%$ of German women. Still, certain professions, such as farmers, self-employed people and civil servants (Beamte), are not included in the dataset. Civil servants work in the public sector; as this group is not included in the German sample, we may disregard a group of women who find it easier than others to combine work and family life (Adserà 2011). While this may cause some bias, civil servants compose only a small fraction of the German population. Even among the public sector employees, civil servants only make up about $35 \%$ of the staff (Statistisches Bundesamt 2012). In addition, studies for Germany, unlike for other countries, find only weak association between public sector employment and fertility behaviour (Gebel and Giesecke 2009; Kreyenfeld and Zabel 2005).

Another disadvantage of the German pension data is that employment and income histories include only episodes that are relevant for calculating pensions.

\footnotetext{
Footnote 4 continued

German Pension Funds, which usually occur at ages 30 and above, make us unable to cover cohorts born in 1977 or later. In a period approach, this means that the youngest ages (20-25) are only represented by very sparse data for the most recent calendar period we study.

5 In Germany, non-natives are normally classified by their citizenship, while in Denmark and other Nordic countries, they are more often defined in the statistics by their country of birth. The same applies to our data.

6 An Eastern German woman is defined as a woman who has ever been employed in the territories of what used to be the Democratic Republic of Germany. This is a rather narrow definition, because it also classifies all East to West migrants as East Germans. However, we had to follow this definition, because earnings information in the registers for the East German population has been subject to special regulations.
} 
These are periods of employment, unemployment, parental leave, education and vocational training. ${ }^{7}$ Some periods spent in education, as well as periods when people were inactive (for example, because they were housewives) are not registered. Because we cannot always differentiate between educational participation and other types of non-employment, our analyses have some limitations. In the German data, income information is recorded in terms of 'earnings points'. Contributions that stem from an average-level income lead in general to a one-credit point in the pension record. The backbone of the calculation in the German pension insurance is the individual contribution made to the pension record. The monthly contributions are measured at the end of each year against the average annual national earnings. ${ }^{8}$

The Danish data cover the entire resident population in any given calendar year. A crucial difference between the Danish and German datasets is that the income information for Denmark is available on an annual rather than monthly basis, as it is collected for the Danish taxation registers. For a given year, we have information on the amount of taxable earnings each Danish woman has received. Another difference between the two datasets is that earnings in Denmark, unlike in Germany, can also include transfer payments, such as unemployment benefits, parental leave payments and other taxable allowances. However, in addition to the earnings status in a given calendar year, we have separate information on educational enrolment from the educational registers of Denmark and on unemployment experience from Danish unemployment insurance registration. This provides a more complete picture of an individual's labour market status in a given calendar year.

\section{Variables}

The dependent variable in our models is the first, second- or third-birth event. Because the German data include monthly earnings information, we have backdated each childbirth by 9 months to guarantee that earnings are measured before any pregnancy. In the Danish data, we have information on annual earnings and use the earnings information of one calendar year to predict the birth rates during the subsequent year.

The major independent variable in our models is female earnings, which we have grouped into income quintiles. As a reference to define the quintiles, we used the income distribution of women (with any earnings) aged 20-44 in 1995 in each

\footnotetext{
7 Vocational training episodes are generally documented in the pension registers. For other types of technical training, up to three years of activity may be documented. Tertiary education is considered for up to eight years of study. Not all periods of education lead to higher pensions: study periods that lead to higher pensions (e.g., all periods of vocational training and school based technical training) are probably better documented than other periods.

8 There is an upper limit to the income considered for the statutory pension insurance, the 'contribution assessment ceiling'. For female earnings, this ceiling is, however, of minor importance since very few women achieve such a high level of earnings.
} 
country. ${ }^{9}$ An alternative approach could have been to use the combined earnings distribution of women and men with earnings. However, we think our approach has greater merit, as the gender gap in earnings is quite large, particularly in the case of West Germany. However, we need to acknowledge at the same time that the crossnational comparison of income quintiles is problematic, because of the different female employment patterns in the two countries. As we generate the earning quintiles on the country-specific distribution, women in the mid-income quintile in Denmark, for example, will have higher absolute earnings than West German women in this earning bracket.

For Germany, we generated a combination factor of the activity status and the earnings variable. Women who are not employed are differentiated by whether they are in education (which contributes to pension rights), unemployed or involved in other unspecified activities. For the employed population, we distinguish the earnings quintile to which the woman belongs. For Denmark, we did not construct a combination variable of activity status and earnings. Instead, we grouped the entire female study population according to their earnings into the five quintiles we defined, and used control dummies for whether a woman had been a student or unemployed during the same year. In virtually all cases of unemployment and study activity during a year, women had some taxable earnings as well; thus all Danish women contributed to the earnings quintiles we have defined. ${ }^{10}$

Table 1 provides an overview of exposure times of risk and event occurrences, by the different levels of our covariates. As can be seen, there are much fewer events available in the German dataset than in the Danish one, because we were only able to access a subsample of the German register data. The summary reveals that relatively large fractions of women in Germany belong to the category 'other'. For childless women, these periods mainly refer to educational spells that do not contribute to pension rights. However, periods when women withdraw from the labour market to become houswives are subsumed under this label, too. Since educational participation after becoming a mother is rare in West Germany, we can conclude from this table that a large proportion of West German women are inactive in the labour market after becoming mothers. Further, the comparison between Denmark and Germany reveals that the fraction of women who belong to the highest earnings deciles increases with childbearing parity in Denmark while the opposite holds in Germany.

\footnotetext{
${ }^{9}$ Earnings information in the Danish data has been deflated. For Germany, no deflation was necessary because we used earning points, which are already deflated.

${ }^{10}$ The differences between the two countries in the definitions of earnings may hamper direct comparison. For this reason, we have conducted a sensitivity analysis where we deleted students, unemployed and, in the case of Germany, 'others' from our study populations. The results for our earnings variable were very much in line with those reported in our next section (results available from authors upon request).
} 
Table 1 Occurrence and exposure table: woman-months at risk and childbirths

\begin{tabular}{|c|c|c|c|c|c|c|}
\hline & \multicolumn{2}{|c|}{ First birth } & \multicolumn{2}{|c|}{ Second birth } & \multicolumn{2}{|c|}{ Third birth } \\
\hline & $\exp (\%)$ & occ & $\exp (\%)$ & occ & $\exp (\%)$ & occ \\
\hline \multicolumn{7}{|l|}{ West Germany $^{\mathrm{a}}$} \\
\hline \multicolumn{7}{|l|}{ Age } \\
\hline $20-22$ & 24 & 5,482 & 6 & 2,325 & 1 & 373 \\
\hline $23-25$ & 22 & 6,796 & 11 & 4,280 & 4 & 1,029 \\
\hline $26-29$ & 20 & 7,356 & 18 & 6,769 & 12 & 2,205 \\
\hline $30-33$ & 12 & 3,347 & 18 & 4,087 & 19 & 2,044 \\
\hline $34-37$ & 9 & 1,164 & 17 & 1,563 & 22 & 1,059 \\
\hline $38-44$ & 14 & 326 & 31 & 395 & 42 & 365 \\
\hline \multicolumn{7}{|c|}{ Age of previous child (years) } \\
\hline $0-1$ & - & - & 14 & 3,405 & 9 & 1,183 \\
\hline $2-3$ & - & - & 17 & 8,729 & 13 & 2,320 \\
\hline 4 & - & - & 6 & 2,333 & 6 & 859 \\
\hline $5-6$ & - & - & 10 & 2,481 & 11 & 1,182 \\
\hline 7 and older & - & - & 53 & 2,471 & 60 & 1,531 \\
\hline \multicolumn{7}{|l|}{ Period } \\
\hline 1981-1984 & 20 & 4,810 & 27 & 4,230 & 28 & 1,622 \\
\hline 1985-1989 & 22 & 5,687 & 24 & 4,557 & 24 & 1,792 \\
\hline 1990-1995 & 26 & 6,427 & 23 & 4,767 & 22 & 1,635 \\
\hline 1996-2001 & 31 & 7,547 & 27 & 5,865 & 26 & 2,026 \\
\hline \multicolumn{7}{|l|}{ Income quintile } \\
\hline Other & 34 & 6,430 & 52 & 12,157 & 59 & 5,104 \\
\hline In education & 11 & 1,001 & 1 & 221 & 1 & 43 \\
\hline Unemployment & 4 & 1,202 & 5 & 1,212 & 3 & 310 \\
\hline Quintile 1 & 7 & 2,150 & 13 & 2,431 & 15 & 808 \\
\hline Quintile 2 & 9 & 3,082 & 9 & 1,329 & 8 & 346 \\
\hline Quintile 3 & 11 & 3,337 & 7 & 765 & 5 & 183 \\
\hline Quintile 4 & 12 & 3,661 & 6 & 683 & 4 & 172 \\
\hline Quintile 5 & 13 & 3,608 & 7 & 621 & 4 & 109 \\
\hline Total & 100 & 24,471 & 100 & 19,419 & 100 & 7,075 \\
\hline \multicolumn{7}{|l|}{ Denmark $^{\mathrm{b}}$} \\
\hline \multicolumn{7}{|c|}{ Age/age higher orders } \\
\hline $20-22$ & 30 & 67,364 & 6 & 14,860 & 1 & 887 \\
\hline $23-25$ & 25 & 120,414 & 15 & 54,691 & 4 & 6,756 \\
\hline $26-28 / 26-29$ & 17 & 134,599 & 32 & 145,001 & 17 & 29,687 \\
\hline $29-31 / 30-33$ & 10 & 84,829 & 26 & 122,084 & 32 & 50,096 \\
\hline $32-34 / 34-37$ & 7 & 38,442 & 14 & 43,197 & 30 & 31,689 \\
\hline $35-37 / 38-44$ & 5 & 15,984 & 7 & 8,953 & 17 & 7,030 \\
\hline $38-40$ & 4 & 5,567 & - & - & - & - \\
\hline $41-43$ & 3 & 1,224 & - & - & - & - \\
\hline
\end{tabular}


Table 1 continued

\begin{tabular}{|c|c|c|c|c|c|c|}
\hline & \multicolumn{2}{|c|}{ First birth } & \multicolumn{2}{|c|}{ Second birth } & \multicolumn{2}{|c|}{ Third birth } \\
\hline & $\exp (\%)$ & occ & $\exp (\%)$ & occ & $\exp (\%)$ & occ \\
\hline \multicolumn{7}{|c|}{ Age of previous child (years) } \\
\hline 0 & - & - & 20 & 2,020 & 12 & 901 \\
\hline 1 & - & - & 19 & 62,071 & 12 & 17,385 \\
\hline 2 & - & - & 15 & 115,047 & 12 & 23,375 \\
\hline $3-4$ & - & - & 19 & 137,865 & 21 & 40,468 \\
\hline $5-6$ & - & - & 13 & 46,624 & 19 & 25,839 \\
\hline $7-9$ & - & - & 14 & 25,159 & 24 & 18,177 \\
\hline \multicolumn{7}{|l|}{ Period } \\
\hline 1981-1985 & 21 & 102,979 & 25 & 86,037 & 24 & 25,253 \\
\hline 1986-1990 & 25 & 116,157 & 25 & 90,569 & 24 & 28,373 \\
\hline 1991-1995 & 25 & 120,808 & 24 & 100,179 & 24 & 33,950 \\
\hline 1996-2001 & 29 & 128,479 & 26 & 112,001 & 29 & 38,569 \\
\hline \multicolumn{7}{|l|}{ Study activity } \\
\hline Some study activity & 43 & 122,911 & 18 & 56,803 & 11 & 14,384 \\
\hline No activity & 57 & 345,512 & 83 & 331,983 & 90 & 111,761 \\
\hline \multicolumn{7}{|l|}{ Unemployment } \\
\hline Some unemployment & 25 & 145,310 & 32 & 130,390 & 26 & 40,289 \\
\hline No unemployment & 75 & 323,113 & 68 & 258,396 & 74 & 85,856 \\
\hline \multicolumn{7}{|l|}{ Income quintile } \\
\hline Quintile 1 & 39 & 87,320 & 18 & 57,034 & 18 & 25,629 \\
\hline Quintile 2 & 16 & 70,749 & 19 & 77,414 & 20 & 27,586 \\
\hline Quintile 3 & 16 & 108,636 & 24 & 99,653 & 24 & 31,068 \\
\hline Quintile 4 & 16 & 117,210 & 22 & 90,783 & 21 & 23,799 \\
\hline Quintile 5 & 14 & 84,508 & 17 & 63,902 & 18 & 18,063 \\
\hline Total & 100 & 468,423 & 100 & 388,786 & 100 & 126,145 \\
\hline
\end{tabular}

exp exposure time at risk, in percentage of all person-months, occ occurrences of births

a For Germany, income refers to labour market earnings. Unemployed, women in education and others (mostly housewives) are listed as separate categories, because they receive no labour market income. ${ }^{\mathrm{b}}$ For Denmark, income includes earnings, earnings-based transfers (such as unemployment benefits) and other taxable transfers. There are basically no housewives, i.e., women with no individual income in the Danish data. We control for any experience of unemployment or study activity during a given calendar year

\section{Results}

\section{Results for Germany}

Table 2 gives the relative risks of first birth for West German women. Model 1 covers all women who can have a first birth, Models $2 \mathrm{a}$ and $2 \mathrm{~b}$ provide separate results by woman's age group, and Models $3 \mathrm{a}$ and $3 \mathrm{~b}$ give separate results by calendar period. We first turn to Model 1. Our control variables provide the 
Table 2 Relative risks of first birth in West Germany, results from piecewise constant event-history model

\begin{tabular}{|c|c|c|c|c|c|}
\hline & $\begin{array}{l}\text { Model } 1 \\
\text { All }\end{array}$ & $\begin{array}{l}\text { Model 2a } \\
20-29\end{array}$ & $\begin{array}{l}\text { Model 2b } \\
30-44\end{array}$ & $\begin{array}{l}\text { Model 3a } \\
1981-1989\end{array}$ & $\begin{array}{l}\text { Model 3b } \\
\text { 1990-2001 }\end{array}$ \\
\hline \multicolumn{6}{|l|}{ Age (years) } \\
\hline $20-22$ & 1 & 1 & & 1 & 1 \\
\hline $23-25$ & $1.22 * * *$ & $1.26 * * *$ & & $1.26^{* * *}$ & $1.25^{* * *}$ \\
\hline $26-29$ & $1.37 * * *$ & $1.43^{* * *}$ & & $1.24 * * *$ & $1.56^{* * * *}$ \\
\hline $30-33$ & 1.02 & & 1 & $0.73 * * *$ & $1.31^{* * *}$ \\
\hline $34-37$ & $0.49 * * *$ & & $0.49 * * *$ & $0.31^{* * *}$ & $0.66^{* * *}$ \\
\hline $38-44$ & $0.08 * * *$ & & $0.09 * * *$ & $0.06^{* * *}$ & $0.13^{* * *}$ \\
\hline \multicolumn{6}{|c|}{ Income and activity } \\
\hline In education & $0.26 * * *$ & $0.25^{* * *}$ & 0.84 & $0.25^{* * *}$ & $0.28^{* * *}$ \\
\hline Other & $0.65 * * *$ & $0.66 * * *$ & $0.61^{* * *}$ & $0.63^{* * *}$ & $0.66^{* * *}$ \\
\hline Unemployment & $1.08 * *$ & $1.11 * * *$ & 0.95 & 0.99 & $1.16^{* * *}$ \\
\hline Quintile 1 & 1 & 1 & 1 & 1 & 1 \\
\hline Quintile 2 & $1.05^{*}$ & $1.05^{*}$ & 1.01 & 0.95 & $1.15^{* * *}$ \\
\hline Quintile 3 & $0.87 * * *$ & $0.88^{* * *}$ & $0.82 * * *$ & $0.81 * * *$ & $0.93 *$ \\
\hline Quintile 4 & $0.91 * * *$ & $0.89 * * *$ & 1.02 & $0.87 * * *$ & 0.97 \\
\hline Quintile 5 & 0.97 & $0.86^{* * *}$ & $1.21 * * *$ & 0.96 & 1.01 \\
\hline \multicolumn{6}{|l|}{ Period } \\
\hline 1981-1984 & 1 & 1 & 1 & 1 & \\
\hline 1985-1989 & 0.97 & $0.94 * * *$ & $1.13^{* * *}$ & $0.96^{*}$ & \\
\hline 1990-1995 & $0.92 * * *$ & $0.85 * * *$ & $1.36^{* * *}$ & & 1 \\
\hline 1996-2001 & $0.85 * * *$ & $0.74 * * *$ & $1.51 * * *$ & & $0.91 * * *$ \\
\hline
\end{tabular}

expected results: there is a bell-shaped relationship between age and first-birth risks; furthermore, first-birth rates decline over calendar time. To a large extent, this is due to postponed motherhood entry: Model 2 reveals how the declines in first-birth rates in the younger age bracket were accompanied by increases at ages 30 and above.

The model also demonstrates a strong impact of educational participation on first-birth propensities. Women who are in education have a $74 \%$ lower first-birth rate than employed women with a low income. 'Other activities' reduce first-birth rates as well, which supports the assumption that for childless women these periods are mainly educational episodes. Unemployed women have somewhat elevated firstbirth risks. Furthermore, the table shows that earnings and first-birth rates are only loosely related. If there is any association, it would best be described as curvilinear with the middle income category having the lowest first-birth rates. In order to correctly interpret these results, one needs to consider that earnings vary across individuals as well as across the life course. If we find that earnings are not associated with first-birth risks, this may indicate that high and low-income women do not differ much in their first-birth behaviour. However, the results may also stem 
from the fact that women do not visibly speed up or postpone parenthood to a later stage in their life course in reaction to their current earnings situation.

Model 2 further addresses this issue by providing separate results by woman's age. At younger ages, low earnings are associated with slightly elevated first-birth fertility; at the higher ages, we find a curvilinear relationship, with low and high earnings associated with somewhat increased first-birth fertility. The elevated firstbirth rates of older high-income earners may be interpreted as a 'catch-up' effect related to a situation where these women have postponed motherhood to a later stage in their life course. Another interesting finding relates to life course variation in the role of female unemployment in first-birth fertility. While unemployment seems to increase first-birth transitions at lower ages, it is unrelated to fertility at the higher ages. The former finding is somewhat surprising as the demographic literature repeatedly suggests that high youth unemployment is a major cause for fertility postponement in contemporary societies (Adserà 2004; Blossfeld et al. 2006; Kreyenfeld 2010; Kreyenfeld et al. 2012; McDonald 2000). However, it conforms with other empirical research that shows that individual unemployment at early ages is indeed connected to elevated first-birth fertility of those concerned (Kreyenfeld and Andersson 2014; Rendall et al. 2009).

Model 3 addresses the question of whether the association of female earnings with first-birth risks has changed over calendar time. The idea behind this assumption is that, in Germany as well as in Denmark, the incompatibility of work and family life may have eased over time, which would suggest that the correlation between female earnings and fertility could have changed direction from the 1980s to the 1990s. However, there is no support for this idea; for both periods, the gradient in the female earnings and first-birth nexus is weak and rather irregular.

Table 3 displays the results for the transition to second and third births. For second births, we find a mostly negative gradient in how female earnings are related to childbearing. Furthermore, women who are not active in the labour market and thus classified as 'others' have relatively high propensities to have a second child; unemployed one-child mothers have the highest propensity to have their second child. The third-birth model does not produce any statistically significant gradient in the association of female earnings with childbearing. Note that the overwhelming majority of two-child mothers in Germany have no labour market earnings at all (Table 1). For these women (labelled 'others'), third-birth risks are much higher than for the employed. The same applies to unemployed two-child mothers. They have more than $60 \%$ higher risks of having a third birth than the reference category of employed women belonging to the lowest earnings quintile.

On the whole, our results suggest that an adequate earnings situation does not appear to be a prerequisite for parenthood and childbearing decisions among West German women. Particularly striking is the lack of a clear gradient in the earningsfirst childbearing relationship and the finding that the propensity to have a child is highly elevated for unemployed mothers and for unemployed childless women in their twenties. For higher-order births, the large group of non-employed women experiences the highest birth rates, showing that the current personal earnings situation is no decisive factor in the childbearing decisions of West German women. 
Table 3 Relative risks of second and third birth in Western Germany, results from piecewise constant event-history model

\begin{tabular}{lll}
\hline & Second birth & Third birth \\
\hline Age of previous child (years) & & \\
$0-1$ & 1 & 1 \\
$2-3$ & $2.21^{* * *}$ & $1.56^{* * *}$ \\
4 & $1.78^{* * *}$ & $1.52^{* * *}$ \\
$5-6$ & $1.27^{* * *}$ & $1.38^{* * *}$ \\
7 and older & $0.52^{* * *}$ & $0.89^{* * *}$ \\
Age of woman (years) & & \\
$20-22$ & 1 & 1 \\
$23-25$ & 0.98 & $0.71^{* * *}$ \\
$26-29$ & 1.03 & $0.53^{* * *}$ \\
$30-33$ & $0.79 * * *$ & $0.36^{* * *}$ \\
$34-37$ & $0.42^{* * *}$ & $0.19^{* * *}$ \\
$38-44$ & $0.08^{* * *}$ & $0.04 * * *$ \\
Income and activity & & \\
In education & $0.53^{* * *}$ & 1.08 \\
Other & $1.04 *$ & $1.40^{* * *}$ \\
Unemployment & $1.13^{* * *}$ & $1.63^{* * *}$ \\
Quintile 1 & 1 & 1 \\
Quintile 2 & $0.94^{*}$ & 1.13 \\
Quintile 3 & $0.79^{* * *}$ & 1.04 \\
Quintile 4 & $0.81^{* * *}$ & 1.11 \\
Quintile 5 & $0.88^{* * *}$ & 0.92 \\
Period & & \\
1981-1984 & 1 & $1.23^{* * *}$ \\
1985-1989 & $1.13^{* * *}$ & $1.10^{* * *}$ \\
1990-1995 & 1.03 & $1.22^{* * *}$ \\
1996-2001 & & \\
\hline
\end{tabular}

$* * * p<0.01 ; * * p<0.05 ; * p<0.10$

Results for Denmark

Table 4 presents the results for first births in Denmark. As expected, educational participation lowers first-birth rates (Model 1); however, this applies only to educational participation at the lower ages (Model 2a). Unemployment is related to elevated first-birth hazards at these ages (Model 2a), but has no effect on transitions to first-time motherhood at the higher ages (Model 2b). This accords with our findings for Germany, where we also found that the effect of study enrolment and female unemployment on first-birth rates differs by the age of the woman (see Table 2). However, when we look at the role of female earnings in first-birth behaviour, we can see that the patterns for Denmark are entirely different from those for Germany. Table 4 reveals a strongly positive association between a woman's 
Table 4 Relative risks of first birth in Denmark, results from piecewise constant event-history model

\begin{tabular}{llllll}
\hline & $\begin{array}{l}\text { Model 1 } \\
\text { All }\end{array}$ & $\begin{array}{l}\text { Model 2a } \\
20-28\end{array}$ & $\begin{array}{l}\text { Model 2b } \\
29-43\end{array}$ & $\begin{array}{l}\text { Model 3a } \\
1981-1990\end{array}$ & $\begin{array}{l}\text { Model 3b } \\
1991-2000\end{array}$ \\
\hline Age (years) & & & & 1 & 1 \\
$20-22$ & 1 & 1 & & 1.55 & 1.75 \\
$23-25$ & 1.60 & 1.61 & & 2.00 & 2.76 \\
$26-28$ & 2.25 & 2.34 & & 1.68 & 2.83 \\
$29-31$ & 2.13 & & 1 & 1.05 & 2.00 \\
32-34 & 1.44 & & 0.68 & 0.55 & 1.14 \\
35-37 & 0.80 & & 0.38 & 0.25 & 0.51 \\
38-40 & 0.37 & & 0.17 & 0.07 & 0.14 \\
41-43 & 0.11 & & 0.05 & 0.72 & 0.73 \\
Study activity & 0.72 & 0.66 & 1.03 & 1.38 & 1.25 \\
Unemployment & 1.32 & 1.41 & 1.01 & & \\
Earnings status & & & & 1 & 1 \\
Quintile 1 & 1 & 1 & 1 & 1.72 & 1.48 \\
Quintile 2 & 1.62 & 1.62 & 1.39 & 2.10 & 2.00 \\
Quintile 3 & 2.09 & 2.05 & 1.88 & 2.17 & 2.14 \\
Quintile 4 & 2.19 & 2.07 & 2.18 & & 2.17 \\
Quintile 5 & 2.21 & 1.80 & 2.31 & 2.10 & \\
Period & & & & & \\
1981-1985 & 1 & 1 & 1.95 & \\
1986-1990 & 0.95 & 0.92 & 1.13 & 0.96 & \\
1991-1995 & 0.99 & 0.89 & 1.40 & & \\
1996-2001 & 0.96 & 0.80 & 1.50 & & \\
\hline No signicance & & & & & \\
\hline
\end{tabular}

No significance levels are reported. As the analyses are based on the entire Danish population, practically any difference in relative risks is significant at a very low probability level. See Hoem (2008) for further reflections on statistical significances

annual earnings and her propensity to become a first-time mother. This result lends support to the idea that Danish women tend to postpone motherhood until they have established themselves in the labour market and attained a sufficient level of earnings. A comparison across age groups reveals a more linear and continuous positive association between female earnings and first-birth fertility at the higher ages (Model 2b). At the lower ages women of the highest earnings quintile still have the possibility to postpone their motherhood entry (Model 2a). A comparison of patterns during the 1980s and 1990s reveals that patterns are very similar in the two decades (Model 3). We do not find much change in the association between earnings and first-birth rates over time.

For second births, female earnings and childbearing are also positively associated with each other but to a much more moderate extent than for first births (see Table 5). Being in the top earnings quintile increases second-birth rates by $26 \%$ compared to being in the lowest quintile. To some extent this positive association for the Danish population may be due to a 'time-squeeze-effect' (Bartus et al. 2013; 
Table 5 Relative risks of second and third births in Denmark, results from piecewise constant eventhistory model

\begin{tabular}{|c|c|c|}
\hline & Second birth & Third birth \\
\hline \multicolumn{3}{|c|}{ Age of previous child (years) } \\
\hline 0 & 0.03 & 0.05 \\
\hline 1 & 1 & 1 \\
\hline 2 & 2.33 & 1.54 \\
\hline $3-4$ & 2.35 & 1.69 \\
\hline $5-6$ & 1.32 & 1.46 \\
\hline $7-9$ & 0.71 & 1.01 \\
\hline \multicolumn{3}{|l|}{ Age (years) } \\
\hline $20-22$ & 1 & 1 \\
\hline $23-25$ & 0.97 & 0.77 \\
\hline $26-29$ & 1.05 & 0.57 \\
\hline $30-33$ & 0.98 & 0.45 \\
\hline $34-37$ & 0.66 & 0.29 \\
\hline $38-44$ & 0.27 & 0.11 \\
\hline Study activity & 0.82 & 0.90 \\
\hline Unemployment & 0.97 & 1.07 \\
\hline \multicolumn{3}{|l|}{ Earnings status } \\
\hline Quintile 1 & 1 & 1 \\
\hline Quintile 2 & 1.15 & 0.89 \\
\hline Quintile 3 & 1.19 & 0.85 \\
\hline Quintile 4 & 1.20 & 0.80 \\
\hline Quintile 5 & 1.26 & 0.85 \\
\hline \multicolumn{3}{|l|}{ Period } \\
\hline 1981-1985 & 1 & 1 \\
\hline 1986-1990 & 1.18 & 1.38 \\
\hline 1991-1995 & 1.38 & 1.80 \\
\hline 1996-2001 & 1.44 & 1.80 \\
\hline
\end{tabular}

No significance levels are reported. As the analyses are based on the entire Danish population, practically any difference in relative risks is statistically significant at a very low probability level. See Hoem (2008) for further reflections on statistical significances

Kreyenfeld 2002): if high income earners space their births closer together to minimize their time of absence from the labour market, this will produce a positive association between female earnings and second-birth rates. Still, these results stand in sharp contrast to the findings for Germany where the level of earnings of a onechild mother is negatively rather than positively associated with her second-birth risk. Contrary to the situation for West Germany, there is also a weak negative association between all dimensions of women's non-employment and second-birth fertility. Women who are in education, who are currently unemployed, or who belong to the lowest earnings quintile all have a somewhat reduced second-birth propensity. 

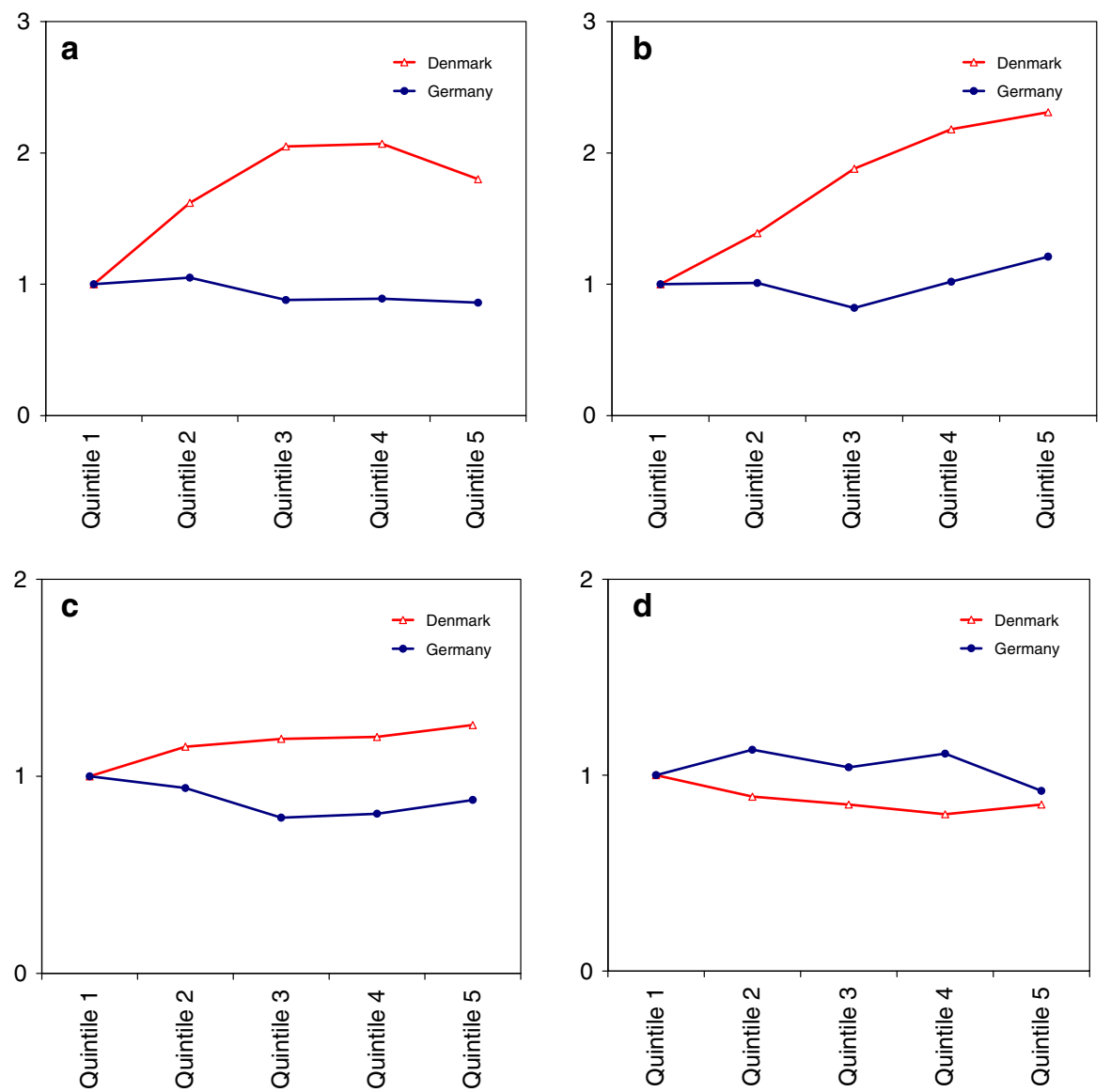

Fig. 3 Relative risks of first, second and third births in Denmark and West Germany, results from piecewise constant event-history model. For full model results, see Tables 2 to 5. a First birth risks, younger ages, $\mathbf{b}$ first birth risks, older ages, $\mathbf{c}$ second birth risks, $\mathbf{d}$ third birth risks

If one turns to third births, the pattern becomes less clear-cut. We find that the association between female earnings and third-birth rates is largely negative. Danish women who belong to the top two income quintiles encounter 15-20\% lower third-birth rates than two-child mothers in the first quintile. Furthermore, the unemployment of a Danish two-child mother is weakly but positively associated with her third-birth risk. Apparently, parental strategies leading to reduced labour-market activity in connection with the building of a large family seem to dominate over any countervailing and positive female 'income effects' on third births. Despite the fact that full-time employment and family life are largely compatible in Denmark, high female earnings do not readily translate into larger family size. Full-time employment may be compatible with raising two children, but less so with having a larger than average family.

Finally, Fig. 3 provides a graphic illustration of our main results for Germany and Denmark: it shows that the association between female earnings and first-time 
motherhood differs radically between the two countries. While Danish women seem to postpone first childbearing until they have reached a sufficiently high level of earnings, the association between female earnings and first-birth fertility is flat in West Germany. Patterns for second births point in the same directions but with less magnitude in the differentials between the two countries. In contrast, we find no support for claims that in Denmark a high female income supports the transition to having a third child.

\section{Conclusion}

In this study, we have used German and Danish register data to investigate the relationship between female earnings, labour market attachment and fertility. We based our empirical research on the hypothesis that the welfare state shapes the female earnings and fertility nexus. In countries like (West) Germany, where work and family life have been rather incompatible, female earnings should be negatively associated with having children. In countries like Denmark that support maternal employment, women will be more inclined to have children once they have established themselves in the labour market. In most cases, having earnings that are sufficient to support a family would be a prerequisite for becoming a mother. A high female income may also provide the earnings power to support a larger family.

On the whole, our empirical estimation provides support for our hypotheses. We find only weak association between female earnings and first-birth risks in Germany, but a strongly positive association between these two variables in Denmark. In this Nordic country, first-birth fertility increases rapidly until women have reached the third earnings quintile. This provides support for the idea that a sufficient female earnings situation is a precondition for forming a family in Denmark. In respect to higher-order births, one needs to consider that West German women often withdraw from the labour market after becoming mothers. These women, who have no labour market earnings, have the highest second and thirdbirth rates. For Denmark, we detect a positive association of second-birth propensities with the level of female earnings and female employment. In particular, women who belong to the lowest income quintile or are unemployed display reduced second-birth rates. All this accords with our expectations. However, for third births the association between female earnings and fertility in Denmark becomes negative. Women in the lowest earnings quintile and those unemployed have higher third-birth rates than other women. Evidently, two-child mothers who reduce their levels of labour market activity are somewhat more inclined than others to aim at a relatively large family size.

To conclude, our analysis provides compelling support for the notion that welfare state contexts shape the associations between women's labour market status, their earnings and their childbearing decisions. In dual-earner regimes like Denmark, women tend to postpone parenthood in their life course until they have established themselves in the labour market and reached sufficiently high earnings. This behaviour is fostered by the Nordic family policy. In Denmark, as in other Nordic countries, parental leave benefits are related to prior earnings, which creates 
incentives for women to reach a sufficient income level before opting for parenthood. This was not the case in West Germany, where parental leave benefits used to be paid on a flat-rate basis.

For second births we generally find less strong variable effects than for first births. People who have opted to become parents also often have a second child within a fairly regular birth interval. Evidently, becoming a parent is a more distinct life course transition than that of having a second child and is more affected by various considerations regarding its appropriate timing. This holds in Denmark as well as in Germany.

For third births, we again find a stronger polarization in behaviour. For Germany, we found clear differences between women who are in the labour market and those who have left it; for Denmark, the findings were somewhat different from those for the lower birth orders. The findings show that research on the role of welfare regimes and economic factors in fertility needs to pay proper attention to birth-order specific differences in behaviour (cf. Andersson 2000; Kreyenfeld and Andersson 2014; Neyer and Andersson 2008).

A great merit of our investigation has been that we were able to draw on register data with longitudinal information on women living in two neighbouring countries in Europe. These data enabled us not only to base our analysis on a sufficiently large number of observations to study how patterns in childbearing vary by birth order, age and calendar period, but also to incorporate highly reliable information on earnings into our study. The drawback was that we were restricted to relatively few variables and unable to distinguish whether the earnings came from part- or fulltime employment. Another caveat is that we had no information on partnership status and any partner's labour market performance; this factor probably matters for childbearing decisions in the male-breadwinner regime of West Germany in particular (Kreyenfeld 2002). Information on this variable would have produced a better understanding of why own female earnings are so loosely related to fertility in West Germany. Nevertheless, this aspect does not invalidate our main finding: a sufficient own income is not a prerequisite for West German women to form a family or to have further children. For Denmark, omitted partner characteristics are less of a concern. Studies on other Nordic countries with similar dual-breadwinner regimes reveal not only that female and male earnings relate very similarly to couples' childbearing behaviour but also that they act relatively independently of each other (Andersson et al. 2005; Andersson and Scott 2007; Jalovaara and Miettinen, 2013).

Our study is instructive for an understanding of the reasons behind the growing divide in aggregate fertility between Denmark and Germany. In both countries, women have flocked into the labour market, since the 1960s and 1980s, respectively. While female employment and female earnings reduce childbearing propensities among West German women, this is not the case in Denmark, where women usually establish themselves in the labour market before becoming mothers and continue to be employed thereafter. Our study has significant social policy relevance. We show that West German women are not reluctant to opt for parenthood and family building when they are unemployed, have low earnings or are not in the labour market, while Danish women opt for parenthood when they are 
well established in the labour market with above-average earnings. It is a hard empirical fact that the wage penalties of motherhood in Denmark and Germany are at opposite extremes among countries in Europe (Gash 2009). The Nordic model of family welfare explicitly builds on principles of social equality and dualbreadwinner responsibilities, but the poor labour market standing of West German mothers is only rarely linked to the circumstances in which they opt for parenthood. The new parental leave reform that was launched in Germany in 2007 sets stronger incentives for women to get established in the labour market before they have children, as parental leave benefits are related to prior earnings. It remains to be seen if this reform has any bearing on the negative association between German women's labour market attachment and childbearing.

Acknowledgments We are grateful for helpful reviewer comments. We also thank for their input Vegard Skirbekk, Gerda Neyer, Sunnee Billingsley, participants at the PAA annual meeting in Dallas, 2010, and at seminars at the Stockholm University Demography Unit and the Max Planck Institute for Demographic Research. For language editing, we thank Miriam Hills. We acknowledge support for our collaboration from Riksbankens Jubileumsfond as well as financial support from the Swedish Research Council (Vetenskapsrådet) via the Linnaeus Center on Social Policy and Family Dynamics in Europe (SPaDE), grant 349-2007-8701, and the Swedish Initiative for Research on Microdata in the Social and Medical Sciences (SIMSAM), grant 839-2008-7495.

Open Access This article is distributed under the terms of the Creative Commons Attribution License which permits any use, distribution, and reproduction in any medium, provided the original author(s) and the source are credited.

\section{References}

Abrahamson, P., \& Wehner, C. (2008). Current issues of family policy in Denmark. In I. Ostner \& C. Schmitt (Eds.): Family policies in the context of family change. The Nordic countries in comparative perspective (pp. 57-74). Wiesbaden: VS Verlag.

Adserà, A. (2004). Changing fertility rates in developed countries. The impact of labor market institutions. Journal of Population Economics, 17, 17-43.

Adserà, A. (2011). Where are the babies? Labor market conditions and fertility in Europe. European Journal of Population, 27, 1-32.

Ahn, N., \& Mira, P. (2002). A note on the changing relationship between fertility and female employment rates in developed countries. Journal of Political Economy, 15, 667-682.

Alich, D. (2006). The third child. A comparison between West Germany and Norway. MPIDR-Working Papers 2006-001. Rostock: Max Planck Institute for Demographic Research.

Andersson, G. (2000). The impact of labour-force participation on childbearing behavior: Pro-cyclical fertility in Sweden during the 1980s and the 1990s. European Journal of Population, 16, 293-333.

Andersson, G., Duvander, A.-Z. \& Hank, K. (2005). Erwerbsstatus und Familienentwicklung in Schweden aus paarbezogener Perspektive [Employment status and family dynamics in Sweden from a couple perspective]. In A. Tölke \& K. Hank (Eds.): Männer-Das 'vernachlässigte' Geschlecht in der Familienforschung [Men-The 'neglected' gender in family research]. Zeitschrift für Familienforschung, Sonderheft 4 (pp. 220-234). Wiesbaden: VS Verlag für Sozialwissenschaften.

Andersson, G., Rønsen, M., Knudsen, L., Lappegård, T., Neyer, G., Skrede, K., et al. (2009). Cohort fertility patterns in the Nordic countries. Demographic Research, 20, 313-352.

Andersson, G., \& Scott, K. (2005). Labour-market status and first-time parenthood: The experience of immigrant women in Sweden, 1981-97. Population Studies, 59, 21-38.

Andersson, G., \& Scott, K. (2007). Childbearing dynamics of couples in a universalistic welfare state: The role of labor-market status, country of origin, and gender. Demographic Research, 17, 897-938. 
Bartus, T., Murinkó, L., Szalma, I., \& Szél, B. (2013). The effect of education on second births in Hungary: A test of the time-squeeze, self-selection, and partner-effect hypotheses. Demographic Research, 28, 1-32.

Becker, G. (1993). A treatise on the family. Cambridge, MA: Harvard University Press.

Berinde, D. (1999). Pathways to a third child in Sweden. European Journal of Population, 15, 349-378.

Bernhardt, E. (1993). Fertility and employment. European Sociological Review, 9, $25-42$.

Berninger, I. (2013). Women's income and childbearing in context: First births in Denmark and Finland. Acta Sociologica, 56, 97-115.

Blossfeld, H.-P., \& Drobniĉ, S. (Eds.). (2001). Careers of couples in contemporary societies: From male breadwinner to dual earner families. Oxford: Oxford University Press.

Blossfeld, H.-P., Mills, M., \& Bernardi, F. (2006). Globalization, uncertainty and men's careers: An international comparison. Cheltenham: Edward Elgar Publishing.

Borchorst, A. (2006). The public- private split rearticulated: Abolishment of the Danish daddy leave. In A. L. Ellingsæter \& A. Leira (Eds.), Politicising parenthood in Scandinavia: Gender relations in welfare states (pp. 101-120). Bristol: Policy Press.

Borg, M. (1989). The income-fertility relationship: Effect of the net price of a child. Demography, 26, 301-310.

Brewster, K., \& Rindfuss, R. (2000). Fertility and women's employment in industrialized countries. Annual Review of Sociology, 26, 271-296.

Brodmann, S., \& Esping-Andersen, G. (2007). When fertility is bargained: Second births in Denmark and Spain. European Sociological Review, 23, 599-613.

Bruning, G., \& Plantenga, J. (1999). Parental leave and equal opportunities: Experiences in eight European countries. Journal of European Social Policy, 9, 195-209.

Budig, M. (2003). Are women's employment and fertility histories interdependent? An examination of causal order using event history analysis. Social Science Research, 32, 376-401.

Castles, F. (2003). The world turned upside down: Below replacement fertility, changing preferences and family-friendly public policy in 21 OECD countries. Journal of European Social Policy, 13, 209-227.

Cedstrand, S. (2011). Från idé till politisk verklighet: Föräldrapolitiken i Sverige och Danmark [From idea to political reality: Parental policy in Sweden and Denmark]. Doctoral Dissertation. Umeå: Boréa Bokförlag.

Crompton, R., \& Lyonette, C. (2006). Work-life 'balance' in Europe. Acta Sociologica, 49, 379-393.

Daly, M. (2005). Changing family life in Europe: Significance for state and society. European Societies, 7, 379-398.

Ellingsæter, A. L. (2009). Leave policy in the Nordic welfare states: A 'recipe' for high employment/high fertility? Community, Work \& Family, 12, 1-19.

Ellingsæter, A. L., \& Leira, A. (Eds.). (2006). Politicising parenthood in Scandinavia: Gender relations in welfare states. Bristol: Policy Press.

Esping-Andersen, G. (1999). Social foundations of postindustrial economies. Oxford: Oxford University Press.

Esping-Andersen, G. (2009). The incomplete revolution. Adapting welfare states to women's new roles. Cambridge: Polity Press.

European Commission (2009). The provision of childcare services. A comparative review of 30 European countries. Brussels: European Commission Directorate-General for Employment, Social Affairs and Equal opportunities, G1 Unit.

Eurostat (2013). Percentage of part-time employment by sex, age groups and household composition. LFS Series 'Ifst_hhptety'. http://epp.eurostat.ec.europa.eu/portal/page/portal/employment_unemployment_ lfs/data/database.

Fine-Davis, M., Fagnani, J., Giovannini, D., Højgaard, L., \& Clarke, H. (2004). Fathers and mothers: Dilemmas of the work-life balance: A comparative study in four European countries. Dordrecht: Kluwer.

Gash, V. (2009). Sacrificing their careers for their families? An analysis of the penalty to motherhood in Europe. Social Indicators Research, 93, 569-586.

Gauthier, A. (2007). The impact of family policies on fertility in industrialized countries: A review of the literature. Population Research and Policy Review, 26, 323-346.

Gebel, M., \& Giesecke, J. (2009). Ökonomische Unsicherheit und Fertilität. Die Wirkung von Beschäftigungsunsicherheit und Arbeitslosigkeit auf die Familiengründung in Ost- und Westdeutschland [Economic uncertainty and fertility: The effect of employment uncertainty and 
unemployment on family formation in East and West Germany]. Zeitschrift für Soziologie, 38, 399-417.

Gornick, J., Meyers, M., \& Ross, K. (1998). Public policies and the employment of mothers: A crossnational study. Social Science Quarterly, 79, 35-54.

Grunow, D. (2006). Convergence, persistence and diversity in male and female careers-Does context matter in an era of globalization? A comparison of gendered employment mobility patterns in West Germany and Denmark. Opladen/Farmington Hill: Barbara Budrich.

Haataja, A. (2009). Fathers' use of paternity and parental leave in the Nordic countries. Working Paper 2/2009 of the Social Insurance Institution of Finland (Kela), Research Department.

Hank, K., \& Kreyenfeld, M. (2003). A multilevel analysis of child care and women's fertility decisions in Western Germany. Journal of Marriage and Family, 65, 584-596.

Henninger, A., Wimbauer, C., \& Dombrowski, R. (2008). Demography as a push toward gender equality? Current reforms of German family policy. Social Politics, 15, 287-314.

Hoem, J. (2008). The reporting of statistical significance in scientific journals: A reflexion. Demographic Research 18(Article 15): 437-442.

Hook, J. (2010). Gender inequality in the welfare state: Sex segregation in housework, 1965-2003. American Journal of Sociology, 115, 1480-1523.

Huinink, J. (2002). Polarisierung der Familienentwicklung in europäischen Ländern im Vergleich [Polarization of family dynamics in European comparison]. Zeitschrift für Familienforschung (Sonderheft 2): 49-73.

Human Fertility Database (2013). Human fertility database. Rostock: Max Planck Institute for Demographic Research. http://www.humanfertility.org/.

Jalovaara, M., \& Miettinen, A. (2013). Does his paycheck also matter? The socio-economic resources of co-residential partners and entry into parenthood in Finland. Demographic Research, 28(31), 881-916.

Kögel, T. (2003). Did the association between fertility and female employment within OECD countries really change its sign? Journal of Population Economics, 17, 45-65.

Konietzka, D., \& Kreyenfeld, M. (2010). The growing educational divide in mothers' employment: An investigation based on the German micro-censuses 1976-2004. Work, Employment \& Society, 24, 260-278.

Konietzka, D., \& Kreyenfeld, M. (Eds.). (2013). Kinderlosigkeit in Deutschland [Childlessness in Germany] (2nd ed.). Wiesbaden: VS Verlag.

Kravdal, Ø. (1992). The weak impact of female labour force participation on Norwegian third-birth rates. European Journal of Population, 8, 247-263.

Kravdal, Ø. (2001). The high fertility of college educated women in Norway: An artefact of the separate modelling of each parity transition. Demographic Research, 5(6), 187-216.

Kravdal, Ø. (2002). The impact of individual and aggregate unemployment on fertility in Norway. Demographic Research, 6, 263-293.

Kreyenfeld, M. (2002). Time-squeeze, partner effect or self-selection? An investigation into the positive effects of women's education on second birth risks in West Germany. Demographic Research, 7, $15-47$.

Kreyenfeld, M. (2010). Uncertainties in female employment careers and the postponement of parenthood in Germany. European Sociological Review, 26, 351-366.

Kreyenfeld, M. \& Andersson, G. (2014). Socio-economic differences in the unemployment and fertility nexus in cross-national comparison. Advances in Life Course Research, 29, 59-73. doi:10.1016/j. alcr.2014.01.007.

Kreyenfeld, M., Andersson, G. \& Pailhé, A. (Eds.) (2012). Economic uncertainty and family dynamics in Europe. Demographic Research, Special Collection 12. Rostock: Max Planck Institute for Demographic Research.

Kreyenfeld, M., \& Geisler, E. (2006). Müttererwerbstätigkeit in Ost- und Westdeutschland [Mothers' employment in Eastern and Western Germany]. Zeitschrift für Familienforschung, 18, 333-361.

Kreyenfeld, M. \& Krapf, S. (2010). Soziale Ungleichheit und Kinderbetreuung-Eine Analyse der sozialen und ökonomischen Determinanten der Nutzung von Kinderbetreuungseinrichtungen [Social inequality and child care: An investigation of the social and economic determinants of child care usage]. In R. Becker \& W. Lauterbach (Eds.): Bildung als Privileg. Erklärungen und Befunde zu den Ursachen der Bildungsungleichheit [Education as a privilege: Explanations and findings on the origins of educational inequalities] (4th ed., pp. 107-128). Wiesbaden: VS Verlag. 
Kreyenfeld, M., \& Mika, T. (2008). Erwerbstätigkeit und Fertilität: Analysen mit der Versicherungskontenstichprobe der deutschen Rentenversicherung [Employment and fertility: Analyses based on data from the German pension fund]. Deutsche Rentenversicherung (Sonderausgabe), 79, 71-95.

Kreyenfeld, M., \& Zabel, C. (2005). Female education and the second child: Great Britain and Western Germany compared. Schmollers Jahrbuch, 125, 145-156.

Lister, R. (2009). A Nordic nirvana? Gender, citizenship, and social justice in the Nordic welfare states. Social Politics, 16, 242-278.

Luci, A., \& Thévenon, O. (2011). Does economic development explain fertility rebound in OECD countries? Population and Societies, 481, 1-4.

Lundström, K. E., \& Andersson, G. (2012). Labor-market status, migrant status and first childbearing in Sweden. Demographic Research, 27, 719-742.

Mandel, H., \& Semyonov, M. (2006). A welfare state paradox: State interventions and women's employment opportunities in 22 countries. American Journal of Sociology, 111, 1910-1949.

Matysiak, A., \& Vignoli, D. (2008). Fertility and women's employment: A meta-analysis. European Journal of Population, 24, 363-384.

Matysiak, A., \& Vignoli, D. (2013). Diverse effects of women's employment on fertility: Insights from Italy and Poland. European Journal of Population, 29, 273-302.

McDonald, P. (2000). Gender equity, social institutions and the future of fertility. Journal of Population Research, 17, 1-16.

Neyer, G. (2013). Welfare states, family policies, and fertility in Europe. In G. Neyer et al. (Eds.): The demography of Europe (pp. 29-53). Dordrecht: Springer. [Also available as Stockholm Research Report in Demography 2012-21.]

Neyer, G., \& Andersson, G. (2008). Consequences of family policies on childbearing behavior: Effects or artifacts? Population and Development Review, 34, 699-724.

Neyer, G., Andersson, G., Hoem, J., Rønsen, M. \& Vikat, A. (2006). Fertilität, Familiengründung und Familienerweiterung in den nordischen Ländern [Fertility, family formation and family building in the Nordic countries]. In H. Bertram et al. (Eds.): Wem gehört die Familie der Zukunft? Expertise zum 7. Familienbericht der Bundesregierung [Who owns the family of the future? Expert report for the 7th Family Commission of the German Government] (pp. 207-233). Opladen: Verlag Barbara Budrich.

Oláh, L. S. (2003). Gendering fertility: Second births in Sweden and Hungary. Population Research and Policy Review, 22, 171-200.

Organization for Economic Co-operation and Development (OECD) (2002). Babies and bosses. Reconciling work and family life, Australia, Denmark and the Netherlands. Paris: OECD.

Organization for Economic Co-operation and Development (OECD) (2012). Employment rate of women (\% of female population 15-64)). doi: 10.1787/20752342-table5.

Özcan, B., Mayer, K. U., \& Luedicke, J. (2010). The impact of unemployment on the transition to parenthood. Demographic Research, 23, 807-846.

Pötzsch, O. (2012). Geburtenfolge und Geburtenabstand. Neue Daten und Befunde [Birth order and spacing: New data and evidence]. Wirtschaft und Statistik 89-101.

Pylkkänen, E., \& Smith, N. (2003). The impact of family-friendly policies in Denmark and Sweden on mothers' career interruption due to childbirth. IZA-Discussion Paper Nr. 1050. Bonn: Institute for the Study of Labor.

Rehfeld, U., \& Mika, T. (2006). The research data center of the German Statutory pension insurance. Schmollers Jahrbuch, 126, 121-127.

Rendall, M., Ekert-Jaffé, O., Joshi, H., Lynch, K., \& Mougin, R. (2009). Universal versus economically polarized change in age at first birth: A French-British comparison. Population and Development Review, 35, 89-116.

Rindfuss, R., \& Brewster, K. (1996). Childrearing and fertility. Population and Development Review, 22(Supplement), 258-289.

Rindfuss, R., Morgan, P., \& Swicegood, G. (1988). First births in America. Berkeley: University of California Press.

Rondinelli, C., Aassve, A., \& Billari, F. (2010). Women's wages and childbearing decisions. Evidence from Italy. Demographic Research, 22, 549-578.

Rønsen, M. (2004). Fertility and public policies. Evidence from Norway and Finland. Demographic Research, 10, 143-170.

Rostgaard, T., Christoffersen, M., \& Weise, H. (1999). Parental leave in Denmark. In P. Moss \& F. Deven (Eds.), Parental leave: Progress or pitfall? Brussels: CBGS Publications. 
Sainsbury, D. (1999). Taxation, family responsibilities, and employment. In D. Sainsbury (Ed.), Gender and welfare state regimes (pp. 185-209). Oxford: Oxford University Press.

Santarelli, E. (2011). Economic resources and the first child in Italy: A focus on income and job stability. Demographic Research, 25, 311-336.

Schmitt, C. (2012a). A cross-national perspective on unemployment and first births. European Journal of Population, 28, 303-335.

Schmitt, C. (2012b). Labour market integration, occupational uncertainty, and fertility choices in Germany and the UK. Demographic Research, 26, 253-292.

Schröder, J. (2010). Der Zusammenhang zwischen der Erwerbstätigkeit von Frauen und ihrer Fertilität [The relationship between female employment and fertility]. Würzburg: Ergon.

Silva, E. (2014). Essays on income and fertility. Lund Studies in Economic History 63. Lund: Lund University.

Sørensen, A. (1991). The restructuring of gender relations in an aging society. Acta Sociologica, 34, $45-55$.

Spitze, G. (1988). Women's employment and family relations: A review. Journal of Marriage and the Family, 50, 595-618.

Statistics Denmark (2013a). Age-specific fertility rates, total fertility rates, gross and net reproduction rate. www.statbank.dk/FOD3.

Statistics Denmark (2013b). Average age of women given birth and new fathers by age and time. www. statbank.dk/FOD11.

Statistisches Bundesamt (2012). Personal des öffentlichen Dienstes [Personnel in the public sector]. Data sheet available at www.destatis.de.

Stegmann, M. (2007). Aufbereitung der Sondererhebung 'Versicherungskonstenstichprobe (VSKT)' als Scientific Use File für das FDZ-RV [The construction of the scientific use file of the German pension data file 'Versicherungskontenstichprobe (VSKT)' for the Research Data Center of the German Pension Fund]. In Deutsche Rentenversicherung Bund (Ed.): Die Versicherungskontenstichprobe als Scientific Use File (pp. 17-33). Berlin: Heenemann.

Thévenon O. (2006). Régimes d'Etat social et convention familiale: Une analyse des régulations emploifamille [Welfare state context and family arrangements: An investigation of work-family regulations]. Economies et Sociétés (Série Socio-Economie du Travail) 27: 1137-1171.

Vignoli, D., Drefahl, S., \& De Santis, G. (2012). Whose job instability affects the likelihood of becoming a parent in Italy? A tale of two partners. Demographic Research, 26, 41-62.

Vikat, A. (2004). Women's labor force attachment and childbearing in Finland. Demographic Research (Special Collection 3): 177-211.

Warren, T. (2001). Divergent female part-time employment in Britain and Denmark and the implications for gender equity. Sociological Review, 49, 548-567. 